\title{
Hubungan Obesitas dan Faktor Risiko Gaya Hidup dengan Hipertensi pada Pasien Puskesmas Kebon Jeruk Desember 2016
}

\author{
Angela Mitchelle Nyangan Anak Prie ${ }^{1}$, Gracia JMT Winaktu² \\ ${ }^{1}$ Fakultas Kedokteran dan Ilmu Kesehatan Universitas Kristen Krida Wacana \\ ${ }^{2}$ Departemen Gizi Fakultas Kedokteran dan Ilmu Kesehatan \\ Universitas Kristen Krida Wacana \\ Alamat Korespondensi: angela.2013fk484@ civitas.ukrida.ac.id
}

\begin{abstract}
Abstrak
Peningkatan tekanan darah atau hipertensi adalah suatu kondisi dimana terjadinya peningkatan tekanan darah arterial yang berlangsung persisten. Salah satu faktor risiko hipertensi adalah obesitas yang terjadi bila terdapat penimbunan lemak akibat asupan kalori yang berlebihan. Selain obesitas, faktor risiko hipertensi yang lain adalah usia, jenis kelamin, riwayat keluarga, merokok, lama merokok, frekuensi merokok, kebiasaan minum kopi dan minuman beralkohol, konsumsi lemak jenuh dan garam, kebiasaan olahraga, dan stress. Tujuan penelitian ini adalah untuk mengetahui hubungan kejadian hipertensi dengan obesitas dan juga usia, jenis kelamin, riwayat keluarga, merokok, lama merokok, frekuensi merokok, kebiasaan minum kopi dan konsumsi minuman beralkohol, konsumsi lemak jenuh dan garam, olahraga, dan stres dengan hipertensi di Puskesmas Kebon Jeruk. Jenis penelitian adalah desain studi potong lintang. Setelah dilakukan uji statistik Chi-square $\left(\mathrm{X}^{2}\right)$, didapatkan hubungan yang signifikan antara obesitas $(\mathrm{p}=0,000)$, usia $(\mathrm{p}=0,001)$, riwayat hipertensi pada keluarga $(\mathrm{p}=0,013)$, kebiasaan merokok $(\mathrm{p}=0,021)$, frekuensi merokok $(\mathrm{p}=0,017)$, konsumsi minuman beralkohol $(\mathrm{p}=0,027)$, dan stress $(\mathrm{p}=0,012)$ dengan kejadian hipertensi. Pada variabel lain dengan nilai $\mathrm{p}>0,05$, yaitu jenis kelamin $(p=0,466)$, lama merokok $(p=0,070)$, kebiasaan minum kopi $(p=0,103)$, konsumsi lemak $(\mathrm{p}=0,626)$, konsumsi garam $(\mathrm{p}=0,913)$, dan olahraga $(\mathrm{p}=0,098)$, tidak didapatkan hubungan yang bermakna dengan hipertensi. Kesimpulan terdapat hubungan antara obesitas, usia, riwayat hipertensi pada keluarga, merokok, frekuensi merokok, konsumsi minuman beralkohol, dan stres dengan hipertensi dan tidak terdapat hubungan antara jenis kelamin, lama merokok, kebiasaan minum kopi, konsumsi lemak jenuh, konsumsi garam, dan kebiasaan olahraga dengan hipertensi pada pengunjung Puskesmas Kebon Jeruk.
\end{abstract}

Kata kunci: tekanan darah, hipertensi, obesitas, faktor risiko

\section{The Correlation between Obesity and Lifestyle Risk Factors with Hypertension among Puskesmas Kebon Jeruk Patients in December 2016}

\begin{abstract}
High blood pressure, also known as hypertension, happens as the long - term force of the blood against the artery walls is high enough it may eventually cause health problems. One of the risk factors of hypertension is obesity that happens when one has excessive amount of body fat mainly due to excessive calorie intake. Other risk factors of hypertension includes age, sex, family history, smoking, coffee and alcoholic drinks consumption, high fat and salt intake, exercise and stress. The purpose of this study is to find the relationship between hypertension with obesity and the aforementioned factors. This is a cross- sectional study with 105 respondents taking part in this study, selected using a consecutive sampling technique. The respondents were all aged 18 and above who were at Puskesmas Kebon Jeruk to receive out patients' treatment at the time of study, excluding those who were known to
\end{abstract}


be on an undergoing treatment for hypertension. Based on the data analysis using Chi-square test, the result shows that there is a relationship between obesity $(p=0.000)$, age $(p=0.001)$, family history $(p=0.013)$, smoking $(p=0.021)$, numbers of cigarettes smoked per day $(p=0.017)$, consumption of alcoholic drinks $(p=0.027)$ and stress $(p=0.012)$ with hypertension. The result, however, showed that there was no significant relationship between sex $(p=0.466)$, years of smoking $(p=0.070)$, coffee consumption ( $p=0.103)$, high fat intake $(p=0.626)$, salt intake $(p=0.913)$ and exercise $(p=0.098)$ with hypertension. The study concludes that there is correlation between hypertension and obesity, family history, smoking, alcohol consumption, and stress among patients at Puskesmas Kebon Jeruk.

Keywords: blood pressure, hypertension, obesity, risk factors

\section{Pendahuluan}

Secara global kasus hipertensi cenderung meningkat dan menjadi salah satu masalah kesehatan utama di banyak negara termasuk Indonesia. ${ }^{1}$

Berdasarkan data World Health Organisation (WHO) pada tahun 2011 terdapat lebih satu miliyar penderita hipertensi di seluruh dunia dengan 9,4 juta kematian setiap tahun, di mana prevalensi hipertensi pada perempuan cenderung lebih tinggi daripada laki-laki. ${ }^{1}$ Di Indonesia, hasil Riset Kesehatan Dasar (Riskesdas) tahun 2013 pula memperlihatkan prevalensi hipertensi di Indonesia yang didapat melalui pengukuran pada umur $\geq 18$ tahun adalah sebesar $25,8 \%$, tertinggi di Bangka Belitung (30,9\%), diikuti Kalimantan Selatan $(30,8 \%)$, Kalimantan Timur $(29,6 \%)$, dan Jawa Barat $(29,4 \%) .{ }^{1}$ DKI Jakarta, prevalensi hipertensi berdasarkan pengukuran adalah sebesar $10,1 \%$. $^{3}$

Hipertensi merupakan suatu kondisi peningkatan tekanan darah arterial abnormal yang berlangsung persisten. Menurut Report from the Panel Members Appointed to the Eighth Joint National Committee (JNC 8), seorang dewasa di atas 18 tahun dinyatakan hipertensi apabila tekanan darah sistolik $\geq 140$ $\mathrm{mmHg}$ atau tekanan darah diastolik $\geq 90$ mmHg. ${ }^{1-2}$

Ada beberapa faktor risiko yang dapat menyebabkan hipertensi. Salah satu di antaranya adalah obesitas. Kejadian hipertensi cenderung meningkat seiring dengan peningkatan prevalensi obesitas. Penelitian di tiga buah negara yaitu, Etiopia, Vietnam, dan Indonesia menunjukkan bahwa risiko hipertensi meningkat lebih tujuh kali lipat pada penduduk dengan obesitas. ${ }^{4-5}$

Obesitas atau kegemukan adalah suatu keadaan yang terjadi jika kuantitas jaringan lemak tubuh dibandingkan dengan berat badan total lebih besar dari keadaan normalnya. Lemak dapat menimbulkan sumbatan pada pembuluh darah sehingga dapat meningkatkan tekanan darah. Menurut WHO, pada tahun 2011, satu dari sepuluh orang dewasa dikategorikan obesitas. ${ }^{1}$ Di Indonesia hasil Riskesdas tahun 2013 menunjukkan prevalensi penduduk laki-laki dewasa obesitas pada tahun 2013 sebanyak $19,7 \%$, lebih tinggi dari tahun $2007(13,9 \%)$ dan tahun 2010 (7,8\%) manakala prevalensi obesitas perempuan dewasa (> 18 tahun) adalah $32,9 \%$, naik $18,1 \%$ dari tahun $2007(13,9 \%)$ dan $17,5 \%$ dari tahun 2010 $(15,5 \%) .^{3} \quad$ Prevalensi penduduk obesitas terendah di provinsi Nusa Tenggara Timur $(6,2 \%)$ dan tertinggi di Sulawesi Utara $(24,0 \%) .{ }^{3}$ DKI Jakarta, dengan prevalensi obesitas sebesar $30,0 \%$ pada laki-laki dan $40,0 \%$ pada perempuan adalah salah satu daripada 16 provinsi dengan prevalensi di atas nasional. ${ }^{5}$

Selain obesitas, faktor risiko hipertensi yang lain adalah seperti usia, jenis kelamin, dan riwayat keluarga dengan hipertensi. Umumnya penderita hipertensi adalah orang yang berusia di atas 40 tahun, namun pada saat ini tidak menutup kemungkinan diderita oleh orang usia muda. ${ }^{6}$ Pada usia sekitar 40 hingga 55 tahun, seorang wanita akan lebih rentan dan berisiko terhadap penyakit karena seiring bertambahnya umur wanita juga akan mengalami premenopause dan cenderung memiliki tekanan darah lebih tinggi daripada laki-laki karena sebelum menopause, wanita relatif terlindungi dari penyakit kardiovaskuler oleh hormon estrogen. ${ }^{6}$ Individu dengan riwayat keluarga hipertensi adalah lebih cenderung untuk menderita hipertensi daripada orang yang tidak mempunyai keluarga dengan riwayat hipertensi. ${ }^{7}$ Gaya hidup dan kebiasaan seperti merokok, konsumsi minuman beralkohol, konsumsi garam berlebihan, konsumsi lemak jenuh, kebiasaan minum kopi, stres dan inaktivitas fisik atau tidak olahraga dengan teratur turut menjadi faktor risiko terjadinya hipertensi. ${ }^{8}$ 


\section{Metodologi Penelitian}

Penelitian dilakukan di Puskesmas Kebon Jeruk pada 1 Desember hingga 31 Desember 2016 dengan responden berjumlah sebanyak 105 orang. Jenis penelitian adalah survei deskriptif - analitik dengan desain studi potong lintang. Sampling yang digunakan adalah secaraconsecutive, mengikutsertakan semua subyek berusia 18 tahun dan ke atas yang datang berobat ke Puskesmas Kebon Jeruk pada bulan Desember 2016 secara berurutan yang memenuhi kriteria inklusi dimasukkan dalam penelitian sampai jumlah penelitian terpenuhi.

Kriteria inklusi dalam penelitian ini adalah semua laki-laki dan perempuan dewasa berusia 18 tahun ke atas yang merupakan bersedia menjadi responden dan dapat berkomunikasi dengan baik. Kriteria eksklusi adalah pengunjung Puskesmas Kebon Jeruk yang merupakan individu atau pasien yang sudah dan sedang menjalani pengobatan hipertensi pada saat penelitian dilakukan.

\section{Hasil Penelitian dan pembahasan}

Dari hasil analisis data yang telah dilakukan, didapatkan 52,4\% responden (55 orang) adalah laki-laki dan $47,6 \%$ (50 orang) adalah perempuan. $27,6 \%$ (29 orang) responden berusia antara 18 hingga 25 tahun, 25,7\% (27 orang) berusia antara 26 hingga 35 tahun, $17,1 \%$ (18 orang) berusia antara 36 hingga 45 tahun, $16,2 \%$ (17 orang) 46 hingga 55 tahun, dan $13,3 \%$ (14 orang) berusia antara 56 hingga 65 tahun. Sebagian besar responden adalah laki - laki dan mayoritas responden berada dalam lingkungan usia 18 hingga 25 tahun.

Setelah dilakukan uji statistik $\mathrm{Chi}$-square $\left(\mathrm{X}^{2}\right)$, didapatkan hubungan yang signifikan antara obesitas $(\mathrm{p}=0,000)$, usia $(\mathrm{p}=0,001)$, riwayat hipertensi pada keluarga $(\mathrm{p}=0,013)$, kebiasaan merokok $(\mathrm{p}=0,021)$, frekuensi merokok $(p=0,017)$, konsumsi minuman beralkohol $(\mathrm{p}=0,027)$, dan stress $(\mathrm{p}=0,012)$ dengan kejadian hipertensi. Pada variabel lain dengan nilai $\mathrm{p}>0,05$, yaitu jenis kelamin $(\mathrm{p}=0,466)$, lama merokok $(\mathrm{p}=0,070)$, kebiasaan minum kopi $(\mathrm{p}=0,103)$, konsumsi lemak $(\mathrm{p}=0,626)$, konsumsi garam $(\mathrm{p}=0,913)$, dan olahraga ( $\mathrm{p}=0,098)$, tidak didapatkan hubungan yang bermakna dengan hipertensi.

Hasil analisis data penelitian mendapatkan sebanyak 57 orang atau 54,3\% responden mempunyai tekanan darah tinggi di Puskesmas
Kebon Jeruk pada bulan Desember 2016 semasa penelitian dijalankan sedangkan hanya 45 orang atau $45,7 \%$ responden tidak hipertensi. Hal ini kemungkinan karena lebih banyak responden yang tidak obesitas, yaitu 60 orang atau $57,1 \%$ sedangkan hanya 45 orang atau $42,9 \%$ responden yang obesitas.

Kebanyakan responden juga tidak merokok, yaitu hanya 65 orang $(61,9 \%)$ sedangkan 40 responden yang lain merokok atau pernah merokok sebelumnya. Kebiasaan merokok dapat meningkatkan risiko hipertensi; hal ini turut tergantung pada lama merokok dan frekuensi merokok seseorang. Dari 40 responden yang merokok atau pernah merokok, hanya 15 orang $(14,3 \%)$ adalah perokok berat yang lama merokok lebih dari 10 tahun dan 11 orang $(10,5 \%)$ yang rata-rata jumlah rokok yang dihisap perhari adalah lebih dari 20 batang. Selain itu juga lebih banyak responden yang tidak mempunyai kebiasaan minum kopi atau minuman beralkohol, tidak suka atau jarang ( $\leq$ satu kali seminggu) mengkonsumsi lemak jenuh dan garam berlebihan. 74 orang $(70,5 \%)$ responden termasuk tidak stress sedangkan hanya 31 orang $(29,5 \%)$ responden yang stress dan lebih berisiko terkena hipertensi.

Akan tetapi, lebih banyak responden yang mempunyai riwayat hipertensi pada keluarga, yaitu 63 orang atau $60,0 \%$ dan hal ini dapat meningkatkan risiko terjadinya hipertensi. Kebanyakan responden juga tidak berolahraga, yaitu 63 orang $(60,0 \%)$ dimana olahraga sering dikaitkan dengan pengelolaan hipertensi selain menurunkan risiko obesitas.

Kejadian hipertensi adalah lebih sering pada responden dengan riwayat hipertensi dalam keluarga. Hal ini sejalan dengan hasil penelitian oleh Sugiharto A di Karanganyar pada tahun 2007 dimana didapatkan responden dengan riwayat keluarga adalah 4,04 kali lebih berisiko untuk terkena hipertensi. ${ }^{19}$ Penelitian lain oleh Loh KW dkk di Perak, Malaysia pada tahun 2013 pula menunjukkan hasil dimana responden dengan riwayat keluarga adalah dua kali lebih rentan untuk mengalami tekanan darah tinggi atau hipertensi. ${ }^{23}$

Hasil penelitian mendapatkan bahwa terdapat hubungan yang bermakna antara merokok dengan hipertensi. Hal sama turut didapatkan pada penelitian oleh Eirmawati C dkk di RSD dr Soebandi Jember pada tahun 2014 dimana responden yang merokok mempunyai risiko 6,429 kali lebih tinggi untuk 
terkena hipertensi dibandingkan dengan responden yang tidak merokok. ${ }^{17}$

Selain kebiasaan merokok, frekuensi merokok juga mempengaruhi kejadian hipertensi. Penelitian oleh Eirmawati dkk di RSD dr Soebandi Jember pada tahun 2014 menunjukkan bahwa seseorang yang merokok lebih dari 20 batang perhari mempunyai risiko 2,490 kali lebih tinggi untuk menderita hipertensi dibandingkan dengan seseorang yang menghisap kurang dari sepuluh batang rokok setiap hari. ${ }^{17}$

Berdasarkan hasil penelitian oleh Palmer A pada tahun 2007 yang dikutip oleh Anggara FHD, mengkonsumsi minuman beralkohol sedikitnya dua kali sehari dapat menyebabkan peningkatan tekanan darah sistolik sebanyak 1,0 $\mathrm{mmHg}$ dan tekanan darah diastolik sebanyak 0,5 mmHg. ${ }^{13}$ Selain itu pada penelitian ini tidak diketahui jenis minuman beralkohol yang dikonsumsi oleh responden karena kada alkohol dalam setiap minuman seperti bir, wine, dan lain-lain adalah berbeda. ${ }^{6}$

Hasil penelitian juga menunjukkan terdapat hubungan antara stres dengan hipertensi. Hal ini sama seperti yang didapatkan pada penelitian yang dilakukan oleh Korneliani dkk pada tahun 2011 di Kecamatan Kalipucang Tasikmalaya yang menemukan bahwa individu yang mengalami stres adalah 6,2 kali (Odd Ratio, OR=6,2) lebih rentan untuk mempunyai tekanan darah tinggi atau hipertensi dibandingkan dengan individu yang tidak stress. ${ }^{12}$ Stres atau ketegangan jiwa dapat memicu peningkatan produksi hormon adrenalin oleh kelenjar adrenal yang kemudiannya menyebabkan peningkatan denyut jantung sehingga terjadinya peningkatan tekanan darah. ${ }^{12}$ Stres meningkatkan tekanan darah untuk sementara waktu; bila stres menghilang dapat kembali normal. ${ }^{12}$ Stres yang berkelanjutan dan tidak dikelola dengan baik akan dapat menyebabkan peningkatan tekanan darah yang menetap. ${ }^{19,22}$

Pada penelitian ini, tidak terdapat hubungan yang bermakna antara jenis kelamin, lama merokok, kebiasaan minum kopi, konsumsi lemak jenuh, konsumsi garam, dan kebiasaan olahraga dengan hipertensi. Hal ini tidak sejalan dengan hasil penelitian-penelitian yang terdahulu. Penelitian oleh Syahrini EN dkk di Puskesmas Tlogosari Kulon Kota Semarang pada tahun 2012 mendapatkan sebanyak $48,7 \%$ responden laki-laki mempunyai tekanan darah tinggi atau hipertensi dan 28,7\% pada responden perempuan dengan hasil uji Chi-square diperoleh nilai $\mathrm{p}=0,161(\mathrm{p}>0,05)$; dimana tidak terdapat hubungan antara jenis kelamin dengan kejadian hipertensi. ${ }^{22}$

\section{Tabel 1. Frekuensi Hipertensi dan Obesitas Responden di Puskesmas Kebon Jeruk Desember 2016}

\begin{tabular}{lcc}
\hline Karakteristik & Frekuensi & $\begin{array}{c}\text { Persentase } \\
(\mathbf{\%})\end{array}$ \\
\hline Obesitas & 45 & 42,9 \\
Ya & 60 & 57,1 \\
Tidak & & \\
Hipertensi & 48 & 45,7 \\
Ya & 57 & 54,3 \\
Tidak & \\
\hline
\end{tabular}


Tabel 2. Distribusi Menurut Jenis Kelamin, Usia, Obesitas, Riwayat Hipertensi pada Keluarga, Kebiasaan Merokok, Frekuensi Merokok, Lama Merokok, Kebiasaan Minum Kopi, Konsumsi Minuman Beralkohol, Konsumsi Lemak Jenuh, Konsumsi Garam, Kebiasaan Olahraga dan Stress Responden di Puskesmas Kebon Jeruk Desember 2016

\begin{tabular}{|c|c|c|}
\hline Karakteristik & Frekuensi & Persentase (\%) \\
\hline \multicolumn{3}{|l|}{ Jenis kelamin } \\
\hline Laki - laki & 55 & 52,4 \\
\hline Perempuan & 50 & 47,6 \\
\hline \multicolumn{3}{|l|}{ Usia } \\
\hline $18-25$ tahun & 29 & 27,6 \\
\hline $26-35$ tahun & 27 & 25,7 \\
\hline $36-45$ tahun & 18 & 17,1 \\
\hline $46-55$ tahun & 17 & 16,2 \\
\hline $56-65$ tahun & 14 & 13,3 \\
\hline \multicolumn{3}{|l|}{ Riwayat hipertensi pada keluarga } \\
\hline Ada & 63 & 60,0 \\
\hline Tidak ada & 42 & 40,0 \\
\hline \multicolumn{3}{|l|}{ Kebiasaan Merokok } \\
\hline Ya / Pernah merokok & 40 & 38,1 \\
\hline Tidak merokok & 65 & 61,9 \\
\hline \multicolumn{3}{|l|}{ Frekuensi merokok } \\
\hline Tidak merokok & 65 & 61,9 \\
\hline $1-10$ batang/hari & 12 & 11,4 \\
\hline $11-20$ batang/hari & 17 & 16,2 \\
\hline$\geq 20$ batang/hari & 11 & 10,5 \\
\hline \multicolumn{3}{|l|}{ Lama merokok } \\
\hline Tidak merokok & 65 & 61,9 \\
\hline$<5$ tahun & 6 & 5,7 \\
\hline $5-10$ tahun & 19 & 18,1 \\
\hline$>10$ tahun & 15 & 14,3 \\
\hline \multicolumn{3}{|l|}{ Kebiasaan minum kopi } \\
\hline Tidak minum kopi & 54 & 51,4 \\
\hline Jarang & 16 & 15,2 \\
\hline Sering & 35 & 33,3 \\
\hline \multicolumn{3}{|l|}{ Konsumsi minuman beralkohol } \\
\hline Tidak minum & 87 & 82,9 \\
\hline Jarang & 6 & 5,7 \\
\hline Sedang & 7 & 6,7 \\
\hline Sering & 5 & 4,8 \\
\hline \multicolumn{3}{|l|}{ Konsumsi lemak jenuh } \\
\hline Tidak / Jarang & 56 & 53,3 \\
\hline Sedang & 23 & 21,9 \\
\hline Sering & 26 & 24,8 \\
\hline \multicolumn{3}{|l|}{ Konsumsi garam } \\
\hline Tidak / Jarang & 56 & 53,3 \\
\hline Sedang & 20 & 19,0 \\
\hline Sering & 29 & 27,6 \\
\hline \multicolumn{3}{|l|}{ Kebiasaan olahraga } \\
\hline Tidak olahraga & 63 & 60,0 \\
\hline Kurang & 26 & 24,8 \\
\hline Cukup & 9 & 8,6 \\
\hline Baik & 7 & 6,7 \\
\hline
\end{tabular}


Tabel 3. Hubungan Antara Hipertensi Dengan Jenis Kelamin, Usia, Obesitas, Riwayat Hipertensi pada Keluarga, Kebiasaan Merokok, Frekuensi Merokok, Lama Merokok, Kebiasaan Minum Kopi, Konsumsi Minuman Beralkohol, Konsumsi Lemak Jenuh, Konsumsi Garam, Kebiasaan Olahraga dan Stress Responden Di Puskesmas Kebon Jeruk Desember 2016

\begin{tabular}{|c|c|c|c|c|}
\hline Variabel & Hipertensi (\%) & Tidak Hipertensi (\%) & Chi-square, $\mathrm{X}^{2}$ & $\mathbf{p}$ \\
\hline \multicolumn{5}{|l|}{ Obesitas } \\
\hline Ya & 73,3 & 26,7 & 24,206 & 0,000 \\
\hline Tidak & 25,0 & 75,0 & & \\
\hline \multicolumn{5}{|l|}{ Jenis kelamin } \\
\hline Laki - laki & 49,1 & 50,9 & 0,531 & 0,466 \\
\hline Perempuan & 42,0 & 58,0 & & \\
\hline \multicolumn{5}{|l|}{ Usia } \\
\hline $18-25$ tahun & 24,1 & 75,9 & & \\
\hline $26-35$ tahun & 29,6 & 70,4 & & \\
\hline $36-45$ tahun & 55,6 & 44,4 & 19,826 & 0,001 \\
\hline $46-55$ tahun & 70,6 & 29,4 & & \\
\hline $56-65$ tahun & 78,6 & 21,4 & & \\
\hline \multicolumn{5}{|l|}{ Riwavat hipertensi pada } \\
\hline \multicolumn{5}{|l|}{ keluarga } \\
\hline Ada & 55,6 & 44,4 & 6,147 & 0,013 \\
\hline Tidak ada & 31,0 & 69,0 & & \\
\hline \multicolumn{5}{|l|}{ Kebiasaan Merokok } \\
\hline Ya / Pernah merokok & 60,0 & 40,0 & 5,314 & 0,021 \\
\hline Tidak merokok & 36,9 & 63,1 & & \\
\hline \multicolumn{5}{|l|}{ Frekuensi merokok } \\
\hline Tidak merokok & 36,9 & 63,1 & & \\
\hline $1-10$ batang/hari & 33,3 & 66,7 & 10,238 & 0,017 \\
\hline $11-20$ batang/hari & 70,6 & 29,4 & & \\
\hline$\geq 20 \mathrm{batang} / \mathrm{hari}$ & 72,7 & 27,3 & & \\
\hline \multicolumn{5}{|l|}{ Lama merokok } \\
\hline Tidak merokok & 36,9 & 63,1 & & \\
\hline$<5$ tahun & 50,0 & 50,0 & 7,046 & 0,070 \\
\hline $5-10$ tahun & 52,6 & 47,4 & & \\
\hline$>10$ tahun & 73,3 & 26,7 & & \\
\hline \multicolumn{5}{|l|}{ Kebiasaan minum kopi } \\
\hline Tidak minum kopi & 37,0 & 63,0 & & \\
\hline Jarang & 43,8 & 56,2 & 4,542 & 0,103 \\
\hline Sering & 60,0 & 40,4 & & \\
\hline \multicolumn{5}{|l|}{ Konsumsi minuman } \\
\hline \multicolumn{5}{|l|}{ beralkohol } \\
\hline Tidak minum & 39,1 & 60,9 & & \\
\hline Jarang & 83,3 & 16,7 & 9,198 & 0,027 \\
\hline Sedang & 71,4 & 28,6 & & \\
\hline Sering & 80,0 & 20,0 & & \\
\hline \multicolumn{5}{|l|}{ Konsumsi lemak jenuh } \\
\hline Tidak / Jarang & 50,0 & 50,0 & & \\
\hline Sedang & 39,1 & 60,9 & 0,938 & 0,626 \\
\hline Sering & 42,3 & 57,7 & & \\
\hline \multicolumn{5}{|l|}{ Konsumsi garam } \\
\hline Tidak / Jarang & 44,6 & 55,4 & & \\
\hline Sedang & 50,0 & 50,0 & 0,183 & 0,913 \\
\hline Sering & 44,8 & 55,2 & & \\
\hline \multicolumn{5}{|l|}{ Kebiasaan olahraga } \\
\hline Tidak olahraga & 52,4 & 47,6 & & \\
\hline Kurang & 46,2 & 53,8 & 6,302 & 0,098 \\
\hline Cukup & 11,1 & 88,9 & & \\
\hline Baik & 28,6 & 71,4 & & \\
\hline \multicolumn{5}{|l|}{ Stress } \\
\hline $\mathrm{Ya}$ & 64,5 & 35,5 & 6,266 & 0,012 \\
\hline Tidak & 37,8 & 62,2 & & \\
\hline
\end{tabular}




\section{Simpulan}

Hasil penelitian menunjukkan terdapat hubungan antara obesitas, usia, riwayat hipertensi pada keluarga, kebiasaan merokok, frekuensi merokok, konsumsi minuman beralkohol, dan stress dengan hipertensi pada pengunjung Puskesmas Kebon Jeruk.

Tidak terdapat hubungan antara jenis kelamin, lama merokok, kebiasaan minum kopi, konsumsi lemak jenuh, konsumsi garam, dan kebiasaan olahraga dengan hipertensi pada pengunjung Puskesmas Kebon Jeruk.

\section{Daftar Pustaka}

1. World Health Organisation. A global brief on hypertension: silent killer, global health crisis. Geneva: WHO Press; 2013.

2. James PA, Oparil S, Carter BL, Cushman WC, Handler J, Lackland DT, et al. Evidence-based guideline for the management of high blood pressure in adults: report from the panel members appointed to the eight joint national committee. JAMA. 2013 December.

3. Badan Penelitian dan Pengembangan Kesehatan. Riset Kesehatan Dasar : Riskesdas 2013. Jakarta: Kementerian Kesehatan RI; 2013:88-90, 132-6,13945,223-5.

4. Tesfaye F, Nawi NG, Van Minh H, Byass $\mathrm{P}$, Berhane $\mathrm{Y}$, Bonita $\mathrm{R}$, Wall $\mathrm{S}$. Association between body mass index and blood pressure across three population in Africa and Asia. Journal of Human Hypertension. 2007;21:28-37.

5. Sherwood L. Fundamentals of human physiology. 4th ed. United States: Brooks \& Cole Cengage Learning; 2012;266-7, 290-3, 485.

6. Sugiharto A. Faktor-faktor risiko hipertensi grade II pada masyarakat. Semarang: Universitas Diponegoro, 2007. Disertasi.

7. Sarwanto, Wilujeng LK, Rukmini. Prevalensi penyakit hipertensi penduduk di Indonesia dan faktor yang berisiko. Buletin Penelitian Sistem Kesehatan. 2009 April;12(2):154-62.

8. Rahajeng E, Tuminah S. Prevalensi hipertensi dan determinannya di Indonesia. Maj Kedokt Indon. 2009; 59(12):580-7.

9. Benjamin IJ, Griggs RC, Wing EJ, Fitz JG, editors. Andreoli and carpenter's cecil essentials of medicine. 9th ed.
Philadelphia: Elsevier Saunders; 2016:240-2, 675-82.

10. Rahayu H. Faktor Risiko hipertensi pada masyarakat RW 01 Srengseng Sawah, Kecamatan Jagakarsa, Kota Jakarta Selatan. Depok: Universitas Indonesia, 2012. Disertasi.

11. Natalia D, Hasibuan P, Hendro. Hubungan obesitas dengan kejadian hipertensi di Kecamatan Sintang, Kalimantan Barat. CDK. 2015;42(5):336-9.

12. Korneliani K, Meida D. Obesitas dan stress dengan kejadian hipertensi. KEMAS. 2012;7(2):117-21.

13. Anggara FHD, Prayitno N. Faktor - faktor yang berhubungan dengan tekanan darah di Puskesmas Telaga Murni, Cikarang Barat tahun 2012. Jurnal Ilmiah Kesehatan. 2013;5(1):20-5.

14. Sigarlaki HJO. Karakteristik dan faktor yang berhubungan dengan hipertensi di Desa Bocor, Kecamatan Bulus Pesantren, Kabupaten Kebumen, Jawa Tengah tahun 2006. Makara Kesehatan. 2006;10(2):788.

15. Pratiwi CE. Hubungan indeks massa tubuh dan kebiasaan merokok dengan kejadian hipertensi pada laki-laki pasien rawat jalan di Puskesmas X. Surakarta: Universitas Muhammadiyah, 2012. Disertasi.

16. Sariana. Faktor-faktor risiko yang dapat dimodifikasi pada kejadian hipertensi di Desa Seri Tanjung Kecamatan Tanjung Batu tahun 2014. Palembang: Universitas Sriwijaya; 2014. Disertasi.

17. Eirmawati C, Wiratmo, Budi PS. Hubungan antara kebiasaan merokok dengan kejadian hipertensi di RSD dr Soebandi Jember. Jurnal Pustaka Kesehatan. 2014;2(2):314-9.

18. Sarasaty RF. Faktor-faktor yang berhubungan dengan hipertensi pada kelompok lanjut usia di Kelurahan Sawah Baru Kecamatan Ciputat Kota Tangerang Selatan tahun 2011. Jakarta: UIN Syarif Hidayatullah, 2011. Disertasi.

19. Suparto. Faktor risiko yang paling berperan terhadap hipertensi pada masyarakat di Kecamatan Jatipuro Kabupaten Karanganyar Tahun 2010 Surakarta: Universitas Sebelas Maret, 2010. Disertasi.

20. Estiningsih HS. Hubungan indeks massa tubuh dan faktor fain dengan kejadian hipertensi pada kelompok usia 18 hingga 
44 tahun di Kelurahan Sukamaju Depok tahun 2012. Depok:Universitas Indonesia, 2012. Disertasi.

21. Dedullah RF, Malonda NSH, Joseph WBS. Hubungan antara faktor risiko hipertensi dengan kejadian hipertensi pada masyarakat di Kelurahan Motoboi Kecil Kecamatan Kotamobagu Selatan. Manado: Universitas Sam Ratulangi, 2013. Disertasi.

22. Syahrini EN, Susanto HS, Udiyono A. Faktor-faktor risiko hipertensi primer di Puskesmas Tlogosari Kulon Kota Semarang. Jurnal Kesehatan Masyarakat. 2012;1(2):315-25.

23. Loh KW, Rani F, Chan TC, Loh HY, Ng $\mathrm{CW}$, Moy FM. The association between risk factors and hypertension in Perak, Malaysia. Med J Malaysia. 2013;68(4):291-6.

24. Setyanda YOG, Sulastri D, Lestari. Hubungan merokok dengan kejadian hipertensi pada laki-laki usia 35 hingga 65 tahun di Kota Padang. Jurnal Kesehatan Andalas. 2015;4(2):434-40.

25. Leone A. Smoking and hypertension. J Cardiolo Curr Res. 2015;2(2):1-7.

26. Martiani A. Faktor risiko hipertensi ditinjau dari kebiasaan minum kopi: studi kasus di wilayah kerja Puskesmas Ungaran. Semarang: Universitas Diponegoro, 2012. Disertasi 